\title{
Comparative Treatments of Waste Municipal Surface Water with Moringa Oleifera Seed and Activated Carbon in Zaria Metropolis, Northern Nigeria
}

\author{
${ }^{1}$ Amina Ibrahim.M, ${ }^{2}$ Batari Musa. L, ${ }^{3}$ Ephraim Audu A, ${ }^{4}$ Gadam Ibrahim .S, ${ }^{5}$ Oddy Obi ifeoma.C \\ ${ }^{6}$ Stella Ezinne. A ${ }^{7}$ Yakubu Obadiah .S, ${ }^{8}$ Olabimtan Olabode. $H^{*}$ \\ ${ }^{1}$ Instructor , ${ }^{2}$ Principal Technologist, ${ }^{3-5}$ Research officer, ${ }^{6}$ Senior Technologist \\ ${ }^{7}$ Research scholar and ${ }^{8}$ Senior Research Technologist \\ 1Aviation Maintenance Engineering Department, \\ Nigeria College of Aviation Technology Zaria Kaduna State, Nigeria
}

2 Principal Technologist

Department of Scientific and Industrial Research,

National Research Institute for Chemical Technology Zaria, Nigeria

3 Research officer

Department of Scientific and Industrial Research,

National Research Institute for Chemical Technology Zaria Kaduna State, Nigeria

4 Research officer

Department of Industrial and Environmental Pollution,

National Research Institute for Chemical Technology Zaria Kaduna State, Nigeria

$$
\begin{gathered}
5 \text { Research officer } \\
\text { Department of Textile Technology, }
\end{gathered}
$$

National Research Institute for Chemical Technology Zaria Kaduna State, Nigeria

6 Senior Technologist

Department of Industrial and Environmental Pollution,

National Research Institute for Chemical Technology Zaria Kaduna State, Nigeria

7 Research scholar

Department of Chemistry,

University of Jos Plateau State, Nigeria

8 Senior Research Technologist

Department of Industrial and Environmental Pollution,

National Research Institute for Chemical Technology Zaria Kaduna State, Nigeria.

\begin{abstract}
This work evaluated Moringa oleifera seed as a bio-coagulant and antimicrobial organic agent for the wholesome purification of five polluted municipal surface water comparatively with activated carbon within Zaria metropolis, Kaduna State, Nigeria. The physicochemical parameters and coliform activities of the raw water samples in contrast to moringa treated and activated carbon treated water samples were established. The water samples were designated as raw water sample (RW), moringa treated water sample (MT) and activated carbon treated water sample (AT).

The pH of the acidic RW was shifted towards neutrality by $6.2 \%$ with AT; Colour and odor were significantly treated with moring a seed and activated carbon; Total dissolved solids were treated by $5.5 \%$ between the RW and MT; Turbidity was reduced between RW and MT by 98\%; Conductivity was controlled by $8.21 \%$ between the RW and AT; DO was restored by $77 \%$ between
\end{abstract}


International Journal of Advances in Scientific Research and Engineering (ijasre), Vol 5 (4), April-2019

the RW and MT. BOD was controlled by $85 \%$ within the RW and AT; COD was controlled by $0.67 \%$ between RW and AT. The total coliform reduction was very effective with MT to AT.

Wastewater treatment combining activated carbon and moringa seed is a promising, effective, cheap, environmentally benign, healthy and sustainable method of water purification that will, directly and indirectly, improve the quality of life, particularly in the rural environments.

Keywords: Activated carbon, Bio-coagulant, Moringa oleifera, Antimicrobial, Water pollution.

\subsection{INTRODUCTION}

Water is a renewable natural resource. Due to ever increasing industrialization, urbanization, this precious resource is constantly under pressure. There are various dimensions to water quality and its deterioration. Water pollution is rendering much of the available water unsafe for consumption. The demands of the increasing population, loss of forest cover, untreated effluent discharge from industries and municipalities, use of non-biodegradable pesticides/ fungicides/ herbicides/ insecticides, use of chemical fertilizers instead of organic manures, etc are causing water pollution.

Furthermore, there are numerous water-borne diseases like cholera, diarrhea, dysentery, etc. which are transmitted by drinking contaminated water.

Thousands of chemicals have been recognized in drinking water sources around the globe and regarded as potentially unsafe to human health at relatively high concentrations [1].

Heavy metals are the largest harmful part of the chemical pollutants and are of specific concern due to their toxicities to humans [2]. Metals and metalloids with atomic weights ranging from 63 to $200.6 \mathrm{~g} / \mathrm{mol}$ and densities greater than $4.5 \mathrm{~g} / \mathrm{cm}^{3}$ are naturally stable [3]. There are 59 elements that are categorized as heavy metals and five out of these are considered to be very toxic and dangerous heavy metals [3]. They include cadmium $(\mathrm{Cd})$, chromium $(\mathrm{Cr})$, copper $(\mathrm{Cu})$, lead $(\mathrm{Pb})$ and $\mathrm{zinc}(\mathrm{Zn})$ which is discharged into the environment by human activities or through natural constituents of the earth's crust. Cadmium pollutants in water may occur from industrial discharge and mining waste [2]. Cadmium contamination is caused by its release in wastewaters and contamination from fertilizers and air pollutants. Cadmium is more toxic than lead and chromium. Cadmium at high levels causes' disease and at low levels over a prolonged period causes high blood pressure, sterility among males, kidney damage and flu disorders [4].

Hence, cadmium removal in water using natural polyelectrolyte such as Moringa seeds would be an advantage [5]. Chromium is widely distributed in the earth's crust and is used in metal plating [6]. In general, food appears to be the major source of chromium intake and on the basis of guideline value, there are no adequate toxicity studies available to provide long-term carcinogenicity study [7]. In epidemiological studies, a relationship has been established between exposure to chromium (VI) by the inhalation route and lung cancer [1]. Copper is both an essential nutrient and a drinking water contaminant [7]. Recent studies have shown effects of copper in drinking water on the gastrointestinal tract, but there is some uncertainty regarding the long term effects of copper on sensitive populations such as carriers of the gene for Wilson disease and other metabolic disorders of copper homeostasis.

Lead in water arises from a number of industrial and mining sources and is the most widely distributed of all toxic metals Lead in water causes serious problems such as anemia, kidney disease and affects the nervous system [7].

Placental transportation of lead in humans affects babies and young children absorb 4-5 times as much lead as adults [1]

The lead toxicant accumulates in the skeleton and causes adverse health effects and interferes with calcium metabolism and with vitamin D metabolism

[4]. However, evidence from studies in humans shows adverse neurotoxic effects other than cancer occurring at very low concentrations of lead [1]. Therefore, there is a need for the removal of lead from all drinking water.

Zinc is an essential trace element found practically all food and potable water in the form of salts or organic complexes [1]. It is found in industrial waste and used in metal plating. Therefore, sources of zinc in water are mainly from industrial discharge and natural sources [8]. The removal of zinc is essential for water treatment processes in producing good quality water [9]. Research is being conducted all over the world to develop more techniques which can generate pure water at low cost. For this reason, various new water purification techniques which have come up to purify water for example by using rechargeable polymer beads, using the seeds of Moringa oleifera tree, purifying water by using aerobic granular sludge technology. Moringa oleifera is one of the most valuable trees in the world; with a vast amount of benefits. The plant possesses many valuable properties which make it of great scientific interest.

The world map is exciting, as we can check that rural and urban populations can easily benefit from the assets of the moringa, but also the poorest people by contributing to their food security, sanitation, drinkable water, and, health in general. Moringa oleifera is the most widely cultivated species of the genus Moringa. It is the sole genus in the flowering plant family Moringaceae. The name is derived from the Tamil word murunggai or the Malayalam word muringa, both of which refer to M. oleifera. 
It contains 13 species from tropical and subtropical climates that vary in size from tiny herbs to massive trees. It is also known as drumstick tree, from the appearance of the long, slender, triangular seed pods, horseradish tree, from the taste of the roots which resembles horseradish, or ben oil tree, from the oil derived from the seeds. The tree itself is rather slender, with drooping branches that grow to approximately $10 \mathrm{~m}$ in height. In cultivation, it is often cut back annually to 1-2 meters and allowed to regrow so the pods and leaves remain within arm's reach [19].

In developing countries, moringa has potential to improve nutrition, boost food security, foster rural development, and maintain sustainable landcare. It may be used as forage for livestock, a micronutrient liquid, a natural anthelmintic, and possible adjuvant.

Moringa seeds are rich in proteins and oil, and, are traditionally used for beauty care [20]. Seeds are also used for water purification. The wood provides a blue dye and it is used for live fences. Medicinal qualities offer to treat diabetes, to enrich anemic blood, to staunch a skin infection, to be an antibiotic, to heal gastric ulcers, and, to care eyes. Thus, this tree offers very interesting opportunities as a food supplement, nutrition, vegetable, oil, water treatment, green manure, foliar spray, natural fertilizer, livestock feed, fodder, medicine, cosmetic and care products [21]. The most recent research has established that crushed moringa seeds are capable of attracting and sticking fast to bacteria and viruses that are found in contaminated and turbid water [22]. The seeds produce positive charges like magnets attracting negative elements of bacteria and other toxic particles [21]. This inspired the development of an innovative natural sanitation water treatment that uses moringa seeds to purify water. This groundbreaking discovery is going to transfigure the sanitation and water treatment practices and will aid significantly in the provision of clean water.

It is perceived that moringa is available in viable quantities and easy to cultivate in the tropical and semiarid belt. Seed harvested for water treatment are allowed to dry naturally on the tree and must be harvested in the dry season. Seeds are round with a brownish semi-permeable seed hull. They have found that when the seeds are dried, crushed and added to water, the seed powder acts as a coagulant binding the particles and bacteria. After a short while the coagulated particles, known as a flock, go down to the bottom and clear water can be poured off. The coagulated solid matter is easily removed. It works on the basis that when mixed with water the crushed seeds produce positively charged proteins which attract the negatively charges particles and bacteria. The mixing action causes them to collide, coagulate and attach to each other: the seeds naturally decrease the turbidity of the raw water by 90 percent leaving clear the water of solids but also removing 90 to 99 percent of the bacteria. Now, it is scientifically proved that Moringa seeds, a natural material locally accessible from villagers, give great purification outcomes, with no harmful effects, better as those obtained with costly commercial chemicals, as alum and chlorine which is known to produce trichloromethane, a cancer precursor [23] and alum (aluminum sulphate) which has been linked to Alzheimer's disease[11]. In addition, the cost of purchasing synthetic coagulants and disinfectants is in hard currency leading to high pricing for treated water in Africa [12]. The coagulative effect of moringa seeds was even better than with Alum and this can be explained with the fact that $M$. oleifera seeds exhibited strong antimicrobial activity [15].

Activated Carbons are the most efficient adsorbents known. It is basically a solid material consisting mainly of pure carbon. A characteristic feature is its porous structure and the resulting immense surface area which may be as large as $1500 \mathrm{~m} / \mathrm{gm}$. Due to its outstanding adsorption qualities, activated carbon is extensively used in process destined to purify, discolor, recuperate and remove odors at low cost and superior efficiency. Adsorption is an interfacial process involving the collection of gaseous or solute components on the surface of adsorbent solids. This phenomenon is associated with physical attractive forces that bind gaseous and solute molecules commonly known as Vander-Waals forces. Adsorption is thus a physical process, i.e. the substances adsorbed on the solid do not undergo any chemical reaction with the latter. The adsorbing solid is referred to as adsorbent and the substance to be adsorbed from the liquid or the gas phase as the solute. The adsorption power and rate is determined by the kind of activated carbon, the particle size, the pore size, and its distribution [13] 


\subsection{EXPERIMENTAL METHODS}

\subsection{Sampling and Analysis}

Polluted raw water samples were obtained from five different locations as; dakace dam, muchia sabon gari, Ahmadu Bello University, Zaria dam and NARICT (National Research Institute for Chemical Technology) senior staff quarters in Zaria, Kaduna State, Nigeria (Fig 1). As a precautionary exercise standard procedures were followed for sample handling and collection [24].

The samples were analyzed for their physical and chemical parameters before treatment

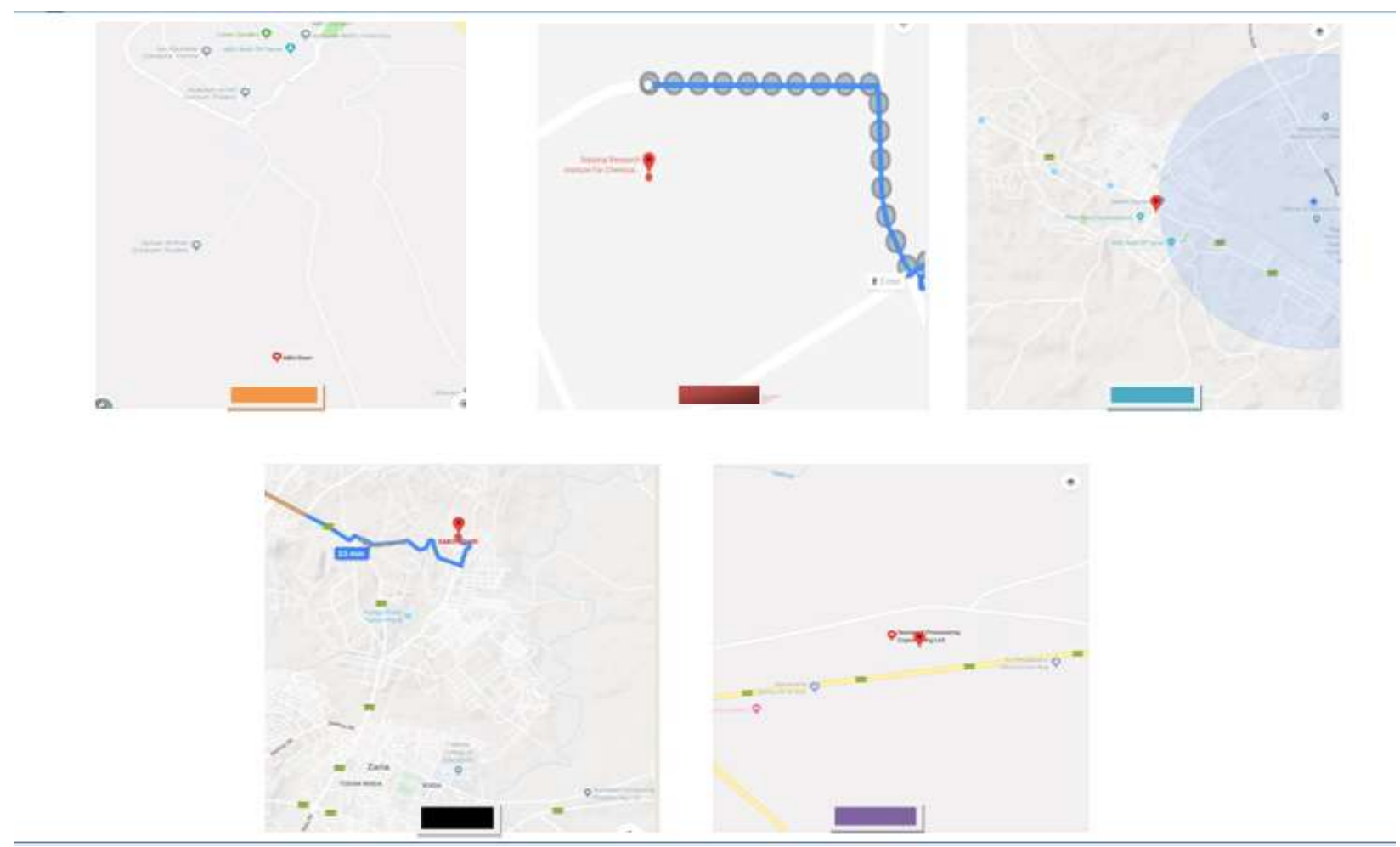

Figure 1.Geological maps of the sampling site

ABU dam

NARICT

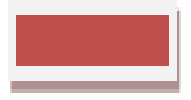

Samaru

Sabongari Dankace 


\subsection{Preparation of moringa seed solution}

The dried seeds were crushed into a fine powder, collected and weighed $1.73 \mathrm{~g}$ into $100 \mathrm{ml}$ of distilled water. The solution was stirred for 5 minutes and allowed to settle for another 1 minute. This was then filtered to achieve a clean solution as filtrate of moringa seed. This was replicated for each of the polluted water samples.

\subsection{Wastewater treatment with moringa seed}

Five clean $500 \mathrm{ml}$ beakers were labeled accordingly with $250 \mathrm{ml} \mathrm{ml}$ of the respective polluted water samples and $100 \mathrm{ml}$ of the filtered moringa seed solution which were thoroughly stirred for $1 \mathrm{~min}$. and allowed to stand for 1hrs [15].An hour after, the particles and contaminants have settled to the bottom as floc. The clear and clean water was carefully decanted into another clean beaker, filtered and stored at $4^{\circ} \mathrm{C}$ for subsequent analysis.

\subsection{Wastewater treatment with Activated carbon}

$8.20 \mathrm{~g}$ of analytical grade activated carbon was weighed in five $10 \mathrm{ml}$ dry and clean beaker each. $100 \mathrm{ml}$ each of the water samples were filtered through the activated carbon in Whatman filter paper with a glass funnel into a $250 \mathrm{ml}$ clean and dry conical flask for the filtrates.

2.5 Biochemical oxygen demand (BOD) determination $1 \mathrm{~L}$ of diluted water was prepared by adding $1 \mathrm{ml}$ of phosphate buffer, magnesium sulfate, calcium chloride and ferric chloride solution to $996 \mathrm{ml}$ of distilled water. About $10 \mathrm{ml}$ from water sample prior and after the treatment was transferred into each BOD bottle. Then, $300 \mathrm{ml}$ of diluted water was added to the BOD bottle. Besides that, $300 \mathrm{ml}$ of diluted water was transferred into the BOD bottle and allocated as the control. Each sample after mixing was then measured using a DO meter. After that, the diluted water was added to the flared mouth of the bottle and covered with aluminum foil to prevent evaporation from the solution. All bottles were then incubated into BOD incubator for 5 days at $20^{\circ} \mathrm{C}$. DO value was measured after 5 days [23].

\subsection{Chemical oxygen demand (COD) measurement}

COD, samples were stabilized by acidifying with $\mathrm{H}_{2} \mathrm{SO}_{4}$ below 2 and it was measured by dichromate titration method [24]

\subsection{Conductivity, pH and total dissolved solids (TDS)}

The electrical conductivity, $\mathrm{pH}$, and TDS were examined using a multifunction PCD 650 waterproof portable meter. The water samples were investigated before and after treatments.

\subsection{Turbidity measurement}

Turbidity test of water samples was measured before and after treatments using 2100P (HACH 44600) turbidity meter [7].

\subsection{Coliform assay}

The antibacterial assay was carried out to investigate the microbiological quality of the water sample. Pour plate method was used to examine the reduction of bacterial population from wastewater samples. This test was conducted prior to and after the treatment by moringa seed and activated carbon.

A serial dilution of the water samples was performed using plating onto the nutrient agar plate before and after the treatment [15]. About $0.1 \mathrm{ml}$ aliquot of each dilution was transferred onto the nutrient agar surface and then evenly spread onto the agar surface using an L-shape glass rod. The plates were then incubated at $37^{\circ} \mathrm{C}$ for overnight. The numbers of colonies that were allowed to grow on the plate were counted. The numbers of colonies before and after the treatment with moringa seed and activated carbon were evaluated. 
International Journal of Advances in Scientific Research and Engineering (ijasre), Vol 5 (4), April-2019

\section{RESULTS AND DISCUSSION}

Table 1. Statistical means and ranges of the physico-chemical parameters

\begin{tabular}{|c|c|c|c|c|c|c|}
\hline \multirow[t]{2}{*}{ Parameters } & \multicolumn{2}{|l|}{ Raw water Samples } & \multicolumn{2}{|l|}{ Moringa Treated } & \multicolumn{2}{|c|}{ Activated carbon Treated } \\
\hline & Mean \pm SD & Range & Mean \pm SD & Range & Mean \pm SD & Range \\
\hline $\mathrm{pH}$ & $6.9340 \pm 0.56336$ & 1.48 & $7.0060 \pm 0.40531$ & 0.95 & $7.4100 \pm 0.26211$ & 0.72 \\
\hline $\mathrm{BOD}(\mathrm{mg} / \mathrm{l})$ & $72.4000 \pm 15.11374$ & 42.50 & $43.8040 \pm 9.14651$ & 25.72 & $18.7880 \pm 3.91885$ & 11.02 \\
\hline $\operatorname{COD}(\mathrm{mg} / \mathrm{l})$ & $63.6100 \pm 6.56948$ & 16.51 & $64.7100 \pm 6.68368$ & 16.80 & $27.2600 \pm 2.81387$ & 7.07 \\
\hline $\mathrm{DO}(\mathrm{mg} / \mathrm{l})$ & $3.3220 \pm 0.36765$ & 0.90 & $11.2520 \pm 1.24144$ & 3.04 & $5.1060 \pm 0.56748$ & 1.39 \\
\hline $\begin{array}{l}\text { Conductivity } \\
(\mu \mathrm{s} / \mathrm{cm})\end{array}$ & $12.8320 \pm 9.19761$ & 19.04 & $13.0800 \pm 7.40723$ & 20.00 & $8.8400 \pm 5.85688$ & 14.00 \\
\hline TDS (mg/l) & $6.4920 \pm 4.72751$ & 10.14 & $6.4600 \pm 3.62188$ & 9.70 & $4.6200 \pm 3.47520$ & 8.30 \\
\hline $\begin{array}{l}\text { Turbidity } \\
\text { (NTU) }\end{array}$ & $182.2380 \pm 226.65669$ & 482.81 & $17.7800 \pm 25.31070$ & 58.15 & $19.4260 \pm 27.77284$ & 63.99 \\
\hline
\end{tabular}

Table 1; Statistical means of the physicochemical parameters.

Table 2. One sample T test of the physico-chemical parameters

\begin{tabular}{|c|c|c|c|c|c|c|c|c|c|c|c|c|}
\hline \multirow[t]{3}{*}{ Parameters } & \multicolumn{4}{|c|}{ Raw water samples } & \multicolumn{4}{|c|}{ Moringa Treated } & \multicolumn{4}{|c|}{ Activated carbon Treated } \\
\hline & \multirow[t]{2}{*}{$\begin{array}{l}\text { Test } \\
\text { value }\end{array}$} & \multirow[t]{2}{*}{$\begin{array}{l}\text { Sig. } \\
\text { (2tailed) }\end{array}$} & \multicolumn{2}{|c|}{$\begin{array}{l}95 \% \text { conf. interval of the } \\
\text { difference }\end{array}$} & \multirow[t]{2}{*}{$\begin{array}{l}\text { Test } \\
\text { value }\end{array}$} & \multirow[t]{2}{*}{$\begin{array}{l}\text { Sig } \\
\text { (2 tailed) }\end{array}$} & \multicolumn{2}{|c|}{$\begin{array}{l}95 \% \text { conf. interval of } \\
\text { the difference }\end{array}$} & \multirow[t]{2}{*}{$\begin{array}{l}\text { Test } \\
\text { value }\end{array}$} & \multirow[t]{2}{*}{$\begin{array}{l}\text { Sig } \\
\text { (2tailed) }\end{array}$} & \multicolumn{2}{|c|}{$\begin{array}{l}95 \% \text { conf. interval of } \\
\text { the difference }\end{array}$} \\
\hline & & & Lower & Upper & & & Lower & Upper & & & Lower & Upper \\
\hline $\mathrm{pH}$ & 7 & 0.806 & -0.7655 & 0.6335 & 7 & 0.975 & -0.4973 & -0.5093 & 7 & 0.025 & 0.0846 & 0.7354 \\
\hline $\mathrm{BOD}[\mathrm{mg} / \mathrm{l})$ & 10 & 0.001 & 43.6338 & 81.1662 & 10 & 0.001 & 22.4471 & 45.1609 & 10 & 0.007 & 3.9221 & 13.6539 \\
\hline $\operatorname{coD}(\mathrm{mg} / \mathrm{l})$ & 250 & 0.000 & -194.5471 & -178.2329 & 250 & 0.000 & -193.5889 & -176.9911 & 250 & 0.000 & -226.2339 & -219.2461 \\
\hline $\mathrm{DO}(\mathrm{mg} / \mathrm{l})$ & 8 & 0,000 & -5.1345 & -4.2215 & 8 & 0.004 & 1.7106 & 4.7934 & 8 & 0.000 & -3.5986 & -2.1894 \\
\hline $\begin{array}{l}\text { Conductivity } \\
(\text { Uc/cm) }\end{array}$ & 1000 & 0.000 & -998.6295 & -976.0505 & 1000 & 0.000 & -996.1173 & -977.7227 & 1000 & 0.000 & -999.3195 & -981.9605 \\
\hline $\operatorname{TDS}\langle\mathrm{mg} / \mathrm{i})$ & 500 & 0.000 & -499.3314 & -487.9246 & 500 & 0.000 & -498.0923 & -488.8277 & 500 & 0.000 & -499.7637 & -490.9163 \\
\hline $\begin{array}{l}\text { Turbidity } \\
\text { (NTU) }\end{array}$ & 5 & 0.155 & -104.1934 & 458.6694 & 5 & 0.322 & -18.6474 & 44.2074 & 5 & 0.310 & -20.0585 & 48.9105 \\
\hline
\end{tabular}

Table 2; one sample T-test of the physic-chemical parameters.
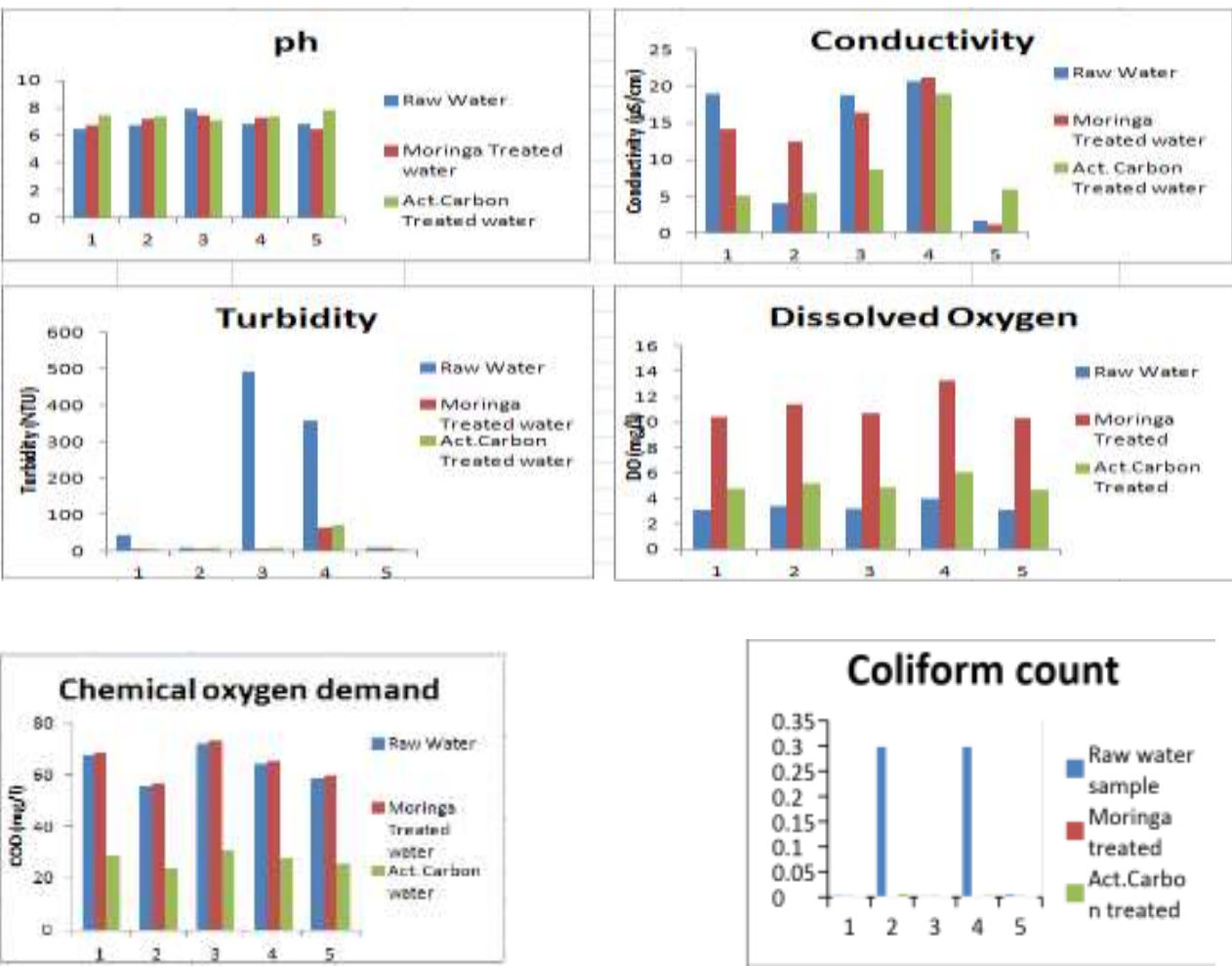

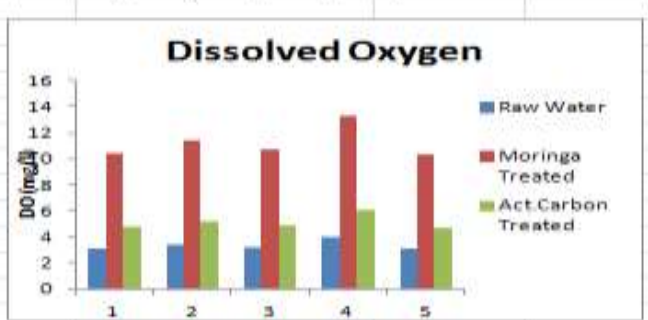

\section{Coliform count}

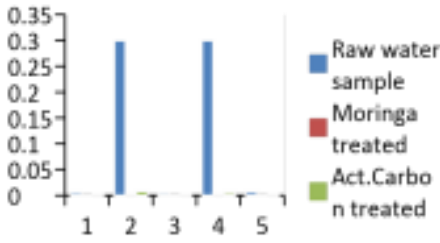

Figure 2. Physico-chemical parameters
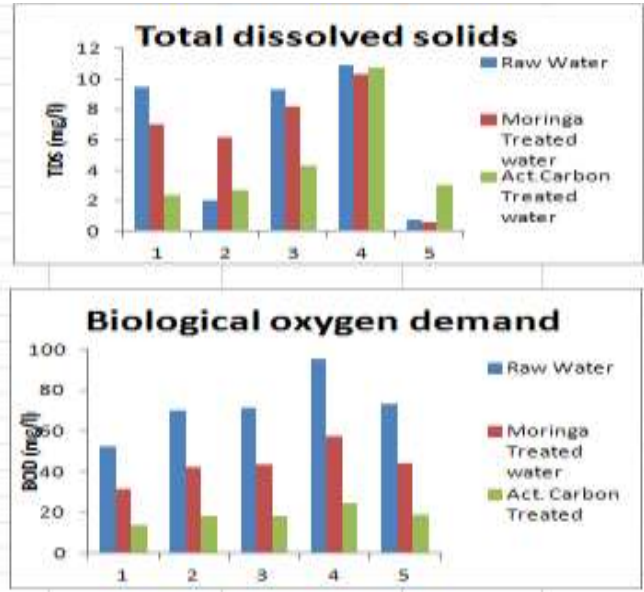
International Journal of Advances in Scientific Research and Engineering (ijasre), Vol 5 (4), April-2019

Table 3. Minimum requirements for drinking water by Nigeria standard for drinking water (NSDW) and world health organization (WHO), 2003

Table 3.Below is the minimum requirements set out by Nigerian standard for drinking water (NSDW) and World Health Organization (2003)

\begin{tabular}{|c|c|c|c|}
\hline Parameter & Unit & $\begin{array}{l}\text { Maximum } \\
\text { permitted }\end{array}$ & Health impact \\
\hline Colour & TCU & 15 & None \\
\hline Odour & $\cdot$ & Unobjectionable & None \\
\hline Taste & - & Unobjectionable & None \\
\hline $\mathrm{pH}$ & - & $6.5-8.5$ & None \\
\hline Sulphate & $\mathrm{mg} / 1$ & 100 & None \\
\hline TDS & $\mathrm{mg} / 1$ & 500 & None \\
\hline Aluminium (Al) & $\mathrm{mg} / 1$ & 0.2 & Potential neuro-degenerative disorders \\
\hline Arsenic $(A s)$ & $\mathrm{mg} / 1$ & 0.01 & Cancer \\
\hline Barium & $\mathrm{mg} / 1$ & 0.7 & Hypertension \\
\hline Cadmium $(C, d)$ & $\mathrm{mg} / 1$ & 0.003 & Toxic to the kidney \\
\hline Chlorine $(C, \mid)$ & $\mathrm{mg} / 1$ & 250 & None \\
\hline Chromium (Cr6+) & $\mathrm{mg} / 1$ & 0.05 & Cancer \\
\hline Conductivity & $\mu \mathrm{S} / \mathrm{cm}$ & 1000 & None \\
\hline Copper (Cu2+) & $\mathrm{mg} / 1$ & 1 & Gastrointestinal disorder \\
\hline Zinc & $\mathrm{mg} / 1$ & 3 & None \\
\hline Cyanide (CN-) & $\mathrm{mg} / 1$ & 0.01 & Very toxic to the thyroid and the nervous system \\
\hline & $\mathrm{mg} / 1$ & 1.5 & Flourosis,skeletal tissue (bones and teeth) morbidity \\
\hline Hardness $(\mathrm{CaCO})$ & $\mathrm{mg} / 1$ & 150 & None \\
\hline Hydrogen Sulphide & $\mathrm{mg} / 1$ & 0.05 & None \\
\hline Iron $(\mathrm{Fe} 2+)$ & $\mathrm{mg} / 1$ & 0.3 & None \\
\hline Lead $\left(\mathrm{P}_{\mathrm{h}}\right)$ & $\mathrm{mg} / 1$ & 0.01 & $\begin{array}{l}\text { Cancer, interference with Vitamin D metabolism, affect mental development } \\
\text { in infants, toxic to the central and peripheral nervous systems }\end{array}$ \\
\hline Magnesium (Mg2†) & $\mathrm{mg} / 1$ & 20 & Consumer acceptability \\
\hline Manganese $(\mathrm{Mn} 2+)$ & $\mathrm{mg} / 1$ & 0.2 & Neurological disorder \\
\hline Mercury (Hg) & $\mathrm{mg} / 1$ & 0.001 & Affects kidney and central nervous system \\
\hline Nickel(Ni) & $\mathrm{mg} / 1$ & 0.02 & Possible carcinogenic \\
\hline Nitrate(N03) & $\mathrm{mg} / 1$ & 50 & Cyanosis and asphyxia (blue baby syndrome) in infants under 3 months \\
\hline Nitrite (NO2) & $\mathrm{mg} / 1$ & 0.2 & Same as above \\
\hline
\end{tabular}

Table 1 presents the statistical means, standard deviation, and ranges of each of the defined parameters prior to treatment (Raw water samples) and after treatments (moringa seed and activated carbon). Increments in the values of pH and Dissolved oxygen after treatment (moringa seed and activated carbon) and reductions in BODs, CODs, Conductivities, TDSs and Turbidities are excellent indicators that the water samples were treated significantly.

Table 2 shows one sample T-test of these same physicochemical properties with their relationship and closeness to their respective standards for potable and drinking water by world health organization and Nigeria standard for drinking water (Table 3).

Their respective standard values were taken as the test values in each case of the parameters and with respect to their lower confidence interval and significance values.

$p H$ was better controlled towards neutrality by activated carbon treatment. BOD, COD, and conductivity were controlled significantly by activated carbon treatment.

DO was significantly restored by moringa seed treatment. Turbidity was practically controlled by both approaches.

Figure 2 also presents the total coliform result of the water samples (Raw and Treated). This account for the bacteria population densities in the water samples 
(Raw and Treated). Moringa treatment was obviously the most effective in clearing the bacteria population.

\section{CONCLUSION}

Moringa oleifera seed is not giving any toxic effects. It is an eco-friendly and cheaper method of purification of water and therefore can be used in rural areas where no facilities are available for the treatment of drinking water. After the treatment of Moringa oleifera seed, sludge gets settled at the bottom of the tank. Large scale treatment at village level produces the large quantity of sludge which can be used as bio-fertilizers and it becomes an added advantage of this treatment. Focus on plant research has increased in recent times all over the world and results have shown an immense potential of some plants in various traditional water purification system [25].

The raw untreated stagnant water from the gutters or drainage had an initial total bacterial count too Numerous to count, which reduced significantly to the bearest minimum colony forming units per ml when treated with moringa seed powder. Moringa oleifera seeds act as a natural coagulant, flocculent, absorbent for the treatment of drinking water. It reduces the total hardness, turbidity, alkalinity, biological/chemical oxygen demand and increases the dissolved oxygen after the treatment. It also acts as a natural antimicrobial agent against the micro-organisms which is present in the drinking water. The total coliform test had shown positive results which indicated the water samples are contaminated by microbes and not safe for drinking. Coliform test count was reduced after treatment with moringa seed powder compared to activated carbon. If moringa oleifera seed powder can be synergized with activated carbon, best results are guaranteed from the treatment of waste and polluted water without the use of conventional toxic and expensive chemicals such as alum and hypochlorite.

This approach will make available good quality, cheap and safer water that will be suitable for drinking especially in rural settlements.

\section{RECOMMENDATIONS}

Further work should be done with respect to heavy metals in comparative studies.

\section{CONFLICT OF INTEREST}

No conflict of interest

\section{ACKNOWLEDGMENT}

Appreciations go to the department of environmental and industrial pollution and control of National Research Institute for Chemical technology Zaria Kaduna state, Nigeria.

\section{REFERENCE}

1. The global burden of disease (2004).World Health Organization. www.who.int/healthinfo/global_burden_disease/2004_report_update/en/

2. Manahan, S.E. (2005) Environmental Chemistry. 8th Edition, CRC Press LLC, New York.

3. Lata, R. and D. Rohindra, (2002). Heavy Metals, in Kurma, J. and Sutcliffe, S. Major Environmental Issues - An Outreach to South Pacific. Chemistry Outreach to Schools, Chemical Society of the South Pacific, USP: Suva: p. 107-108.

4. Baird, C., (1999). Environmental Chemistry: Second Edition. W.H. Freeman and Company, New York.

5. Muyibi, S., Mohd. Noor, M., Leong, T., \& Loon, L. (2002). Effects of Oil Extraction from Moringa Oleifera Seeds on Coagulation Of Turbid Water. International Journal of Environmental Studies, 59(2), 243-254. doi: 10.1080/00207230210924

6. (2019). Retrieved from https://pdfs.semanticscholar.org/43fd/7b65bcba84299c67a9e330cd99b73fa8cc0f.pdf

7. (2019). Retrieved from https://pdfs.semanticscholar.org/43fd/7b65bcba84299c67a9e330cd99b73fa8cc0f.pdf

8. (2019).Retrievedfrom

https://www.researchgate.net/publication/253645614_Water_Purification_using_Moringa_oleifera_and_Other_Locally_Availab 1 e_Seeds_in_Fiji_for_Heavy_Metal_Removal

9. Fatoki, O., \& Ogunfowokan, A. (2002). Effect of coagulant treatment on the metal composition of raw water. Water $S A, 28(3)$. doi: $10.4314 /$ wsa.v28i3.4897

10. (2019).Retrievedfrom

https://www.researchgate.net/publication/266608213_Studies_on_the_potential_use_of_Medicinal_Plants_and_Macrofungi_Lo wer_plants_in_water_and_waste_water_purification

11. Is There a Link Between Aluminum and Alzheimer's? | Cognitive Vitality | Alzheimer's Drug Discovery Foundation. (2019). Retrieved from https://www.alzdiscovery.org/cognitive-vitality/blog/is-there-a-link-between-aluminum-and-alzheimers

12. (2019) Retrieved

from https://www.researchgate.net/publication/247177296_A_Preliminary_Study_on_Cactus_as_Coagulant_in_Water_Treatment 13. Russell, B., \& Levan, M. (1994). Pore size distribution of BPL activated carbon determined by different methods. Carbon, 32(5), 845-855. doi: 10.1016/0008-6223(94)90041-8

14. (2019). Retrieved from http://www.environment.nsw.gov.au/resources/water/approvedmethods-water.pdf 
International Journal of Advances in Scientific Research and Engineering (ijasre), Vol 5 (4), April-2019

15. (2019).Retrievedfrom http://www.imedpub.com/articles/coagulation-and-antimicrobial-activities-of-moringa-oleiferaseedstorage-at-3c-temperature-in-turbid-water.pdf

16. (2019).Retrievedfrom

https://www.researchgate.net/publication/310765849_The_use_of_Moringa_oleifera_seed_as_a_natural_coagulant_for_wastew ater_treatment_and_heavy_metals_removal.

17. (2019).Retrievedfrom

https://sswm.info/sites/default/files/reference_attachments/AMAGLOH\%20BENANG\%202009\%20Effectiveness\%20of\%20Mo ringa\%20Seed $\% 20$ as $\% 20$ Coagulant $\% 20$ for $\% 20$ Water\%20Purification.pdf

18. (2019).Retrievedfrom

https://www.researchgate.net/publication/310765849_The_use_of_Moringa_oleifera_seed_as_a_natural_coagulant_for_wastew ater_treatment_and_heavy_metals_removal

19. Joshi et al, 2012. (2019). Retrieved from https://link.springer.com/content/pdf/10.1007/s13201-016-0499-8.pdf

20. Beauty and Health Benefits of Moringa | You Beauty. (2019). Retrieved from https://www.youbeauty.com/beauty/beauty-and-health-benefits-of-moringa/

21. (2019). Retrieved from https://www.globalgiving.org/pfil/1477/projdoc.pdf

22. (2019). Retrieved from http://shodhganga.inflibnet.ac.in/bitstream/10603/19613/14/14_chapter4.pdf

23. (2019).Retrievedfrom

https://www.researchgate.net/publication/266608213_Studies_on_the_potential_use_of_Medicinal_Plants_and_Macrofungi_Lo wer_plants_in_water_and_waste_water_purification

24. APHA. (1998) Standard Methods for the Examination of Water and Wastewater. American Public Health Association, 20th edition, Washington. D.C. - Open Access Library. (2019). Retrieved from http://www.oalib.com/references/7508047

25. (2019). Retrieved from http://www.iosrjournals.org/iosr-jdms/papers/Vol14-issue4/Version-9/H014493541.pdf 